\title{
Pengembangan SDM Syariah Melalui Perguruan Tinggi: Studi Kasus di Program Studi Manajemen Perbankan Syariah FAI UMJ
}

\author{
Hamli Syaifullah \\ Universitas Muhammadiyah Jakarta \\ hamlisyaifullah@umj.ac.id
}

\begin{abstract}
This study wants to find out how big is the role of Higher Education that provides Islamic Banking Management to produce qualified, qualified human resources, and according to the wishes of the Islamic Banking industry. This research takes a case study in the Islamic Banking Management, Faculty of Islamic StudiesJakarta Muhammadiyah University, in order to get more focused research. In analyzing data, researchers used a qualitative descriptive method. From this study, the researcher proposes that all Higher Education that have the Islamic Banking Management direct the curriculum required by the Islamic Banking industry.
\end{abstract}

Keywords: Islamic Banking, Islamic Banking Management Study Program, Islamic Human Resources

\begin{abstract}
Abstrak
Penelitian ini bertujuan untuk mengetahui seberapa besar peranan Perguruan Tinggi yang menyediakan Program Studi Manajemen Perbankan Syariah untuk menghasilkan SDM Syariah yang mumpuni, kredibel, dan sesuai keinginan industri Perbankan Syariah. Penelitian ini mengambil studi kasus di Program Studi Manajemen Perbankan Syariah, Fakultas Agama Islam - Universitas Muhammadiyah Jakarta, demi mendapatkan penelitian yang lebih fokus. Dalam menganalisis data, peneliti menggunakan metode deskriptif kualitatif. Dari penelitian ini, peneliti mengusulkan agar seluruh Perguruan Tinggi yang menyelenggarakan Program Studi Manajemen Perbankan Syariah, mengarahkan kurikulum yang dibutuhkan oleh industri Perbankan Syariah.
\end{abstract}

Kata Kunci: Perbankan Syariah, Program Studi Manajemen Perbankan Syariah, SDM Syariah

\section{PENDAHULUAN}

Tumbuhnya kesadaran masyarakat Indonesia untuk menggunakan jasa keuangan non-ribawi, berimplikasi positif terhadap eksistensi Bank Syariah di Indonesia. Sistem bagi hasil yang dikembangkan oleh bank syariah, menjadi pembeda dan memberikan daya terik tersendiri bagi masyarakat (Saekhu, 2017: 105). Dengan sistem bagi hasil, Bank Syariah akan terhindar dari adanya negative spread (Muniaty Aisyah, 2018: 368). Hal tersebut dapat dilihat, semenjak berdiri Bank Syariah pertama yaitu Bank Muamalat Indonesia pada tahun 1991 dan mulai beroperasi di tahun 1992, telah memicu pertumbuhan, baik secara jumlah bank ataupun secara jumlah aset. 
Sehingga membuat pangsa pasar Bank Syariah terus tumbuh, walaupun tumbuh perlahan-lahan (Rodoni dan Yaman, 2018: 404).

Tentu saja, tumbuhnya industri Perbankan Syariah tak dapat dipisahkan oleh dua faktor, yaitu internal dan eksternal. Faktor internal meliputi Sumber Daya Manusia (SDM), pendanaan, good corporate governance. Sementara, untuk faktor eksternal seperti pertumbuhan ekonomi dan infrastruktur kelembagaan keuangan syariah nasional maupun internasional (Apriyanti, 2018: 84). Kedua faktor tersebut, saling menopang dalam pengembangan pertumbuhan Bank Syariah di Indonesia, demi mewujudkan kemaslahatan dan sekaligus menghindarkan mafsadah sebagai inti dari Maqāṣid al-Sharī'ah (Anggraini, Rohmati, Widiastuti, 2018: 296). Dimana, mengedepankan kemaslahatan dan mencegah mafsadah, adalah tujuan agama yang paling penting (Kayadibi, 2019: 16).

Menurut data yang dikeluarkan oleh Otoritas Jasa Keuangan (OJK), Pertumbuhan secara jumlah bank, mulai dari Bank Umum Syariah (BUS), Unit Usaha Syariah (UUS), dan Bank Pembiayaan Rakyat Syariah (BPRS), hingga tahun 2018 telah berjumlah 201, sementara untuk aset berjumlah Rp 489.688 triliun (OJK, 2018: 2). Untuk mengetahui perkembangan 4 tahun terakhir, dapat dilihat Tabel 1 di bawah ini.

\section{Tabel 1}

Jumlah Pertumbuhan Bank Syariah di Indonesia

\begin{tabular}{c|l|c|c|c|c}
\hline No & \multicolumn{1}{|c|}{ Keterangan } & \multicolumn{4}{c}{ Tahun } \\
\hline & \multicolumn{2}{|c|}{$\mathbf{2 0 1 5}$} & $\mathbf{2 0 1 6}$ & $\mathbf{2 0 1 7}$ & $\mathbf{2 0 1 8}$ \\
\hline $\mathbf{1 .}$ & Bank Umum Syariah (BUS) \\
\hline & Jumlah Bank & 12 & 13 & 13 & 14 \\
\hline & $\begin{array}{l}\text { Jumlah Aset } \\
\text { (Triliun) }\end{array}$ & 213.423 & 254.184 & 288.027 & 316.691 \\
\hline $\mathbf{2 .}$ & Unit Usaha Syariah (UUS) & & \\
\hline & Jumlah Bank & 22 & 21 & 21 & 20 \\
\hline & $\begin{array}{l}\text { Jumlah Aset } \\
\text { (Triliun) }\end{array}$ & 82.839 & 102.320 & 136.154 & 160.636 \\
\hline & Bank Pembiayaan Rakyat Syariah (BPRS) & 167 \\
\hline & Jumlah Bank & 163 & 166 & 167 & 12.361 \\
\hline 4. & $\begin{array}{l}\text { Jumlah Aset } \\
\text { (Triliun) }\end{array}$ & 7.739 & 9.157 & 10.840 & \\
\hline & Jumlah UUS, BPRS & 197 & 200 & 201 & 201 \\
\hline & $\begin{array}{l}\text { Jumlah Aset } \\
\text { (Triliun) }\end{array}$ & 304.001 & 365.661 & 435.021 & 489.688 \\
\hline
\end{tabular}

Sumber: OJK, Statistik Perbankan Syariah, 2018

Perbankan Syariah di Indonesia, bukan sekadar tumbuh secara kuantitas aset, jumlah bank, dan jumlah kantor, akan tetapi juga diikuti kestabilan kualitas aset yang dikelola. Hal tersebut dapat dilihat dari laporan keuangan per Desember 2018 untuk BUS (Bank Umum Syariah), FDR berjumlah 
Pengembangan SDM Syariah Melalui Perguruan Tinggi: Studi Kasus di Program Studi Manajemen Perbankan Syariah FAI UMJ

78,53\%, CAR 20,39\%, dan NPF 3,6\%. Sementara untuk UUS (Unit Usaha Syariah), FDR berjumlah 103,22\% dan NPF 2,15\%. Sedangkan untuk BPRS (Bank Pembiayaan Rakyat Syariah), FDR berjumlah 111,675, CAR 19,33\%, dan NPF 9,30\% (OJK, 2018: 2).

Walaupun dari data tersebut masih ada beberapa catatan penting yang harus diperhatikan, misalnya untuk NPF BPRS melebihi ketentuan regulator yang harusnya hanya 5\% (BI, 2015: 13; 0JK, 2017: 6). Berkaitan dengan tingginya NPF, menurut penelitian yang dilakukan oleh Dhiba, Esya, Galerry (2019: 15) NPF dalam jangka pendek mempunyai hubungan negatif dan signifikan, sedangkan dalam jangka panjang mempunyai hubungan yang negatif dan tidak signifikan terhadap pertumbuhan aset Perbankan Syariah di Indonesia. Hanya saja, acuan 5\% dari BI dan OJK sebagai regulator, harus tetap diikuti. Kemudian, FDR untuk BPRS yang melebihi ketentuan regulator yaitu maksimal 110\%. Tetapi, untuk CAR mulai dari BUS dan BPRS telah memenuhi dari ketentuan regulator yaitu 8\%. Serta FDR untuk BUS dan UUS telah berada di angka maksimal yang ditetapkan oleh regulator, yaitu di atas $75 \%$.

Data tersebut menunjukkan bahwa jumlah, aset, dan kualitas pengelolaan aset, secara umum menunjukkan keberadaan Perbankan Syariah cukup diminati oleh masyarakat Indonesia. Hal tersebut sejalan dengan penelitian yang dilakukan oleh Abrar, Ahmed, dan Kashif (2018: 362) bahwa ketika pengembalian aset (pembiayaan) bank meningkat, stabilitas keuangan bank juga meningkat. Tentu saja, peningkatan stabilitas keuangan Bank Syariah, bila dikaitkan dengan jumlah mayoritas umat Islam yang ada di Indonesia. Menjadi peluang yang besar untuk pengembangan Bank Syariah di Indonesia ke depannya. Menurut data yang dikeluarkan oleh The Pew Forum on Religion \& Public Life, penganut agama Islam tahun 2016 di Indonesia sebesar 209,1 juta jiwa, atau sebesar 87,2 persen dari total penduduknya. Jumlah tersebut, merupakan 13,1 persen dari seluruh umat muslim di dunia (katadata.co.id 2016).

Besarnya jumlah masyarakat muslim seperti yang diungkap oleh The Pew Forum on Religion \& Public Life, mengindikasikan bahwa pangsa pasar Bank Syariah di Indonesia cukup besar. Artinya, Bank Syariah memiliki potensi untuk berkembang lebih besar ke depannya. Sehingga keberadaan Bank Syariah manfaatnya dapat dirasakan oleh seluruh masyarakat Indonesia. Sebagaimana yang diamanatkan dalam UU No. 21 Tahun 2008 tentang Perbankan Syariah, yaitu dalam rangka meningkatkan taraf hidup rakyat.

Mengacu terhadap pandangan yang diungkap oleh Apriyanti (2018: 86), keberadaan SDM menjadi salah satu faktor internal yang menentukan pengembangan Bank Syariah. Sehingga maju dan mundurnya Bank Syariah akan tergantung kepada SDM yang handal. Semakin handal SDM yang dimiliki, akan semakin berkembang keberadaan Bank Syariah.

Pandangan tersebut, sejalan dengan hasil penelitian yang dilakukan oleh Rusydiana (2016: 224), yang menyatakan bahwa ada empat hal penting dalam pengembangan Bank Syariah, yaitu: SDM, teknikal, aspek legal atau 
struktural, dan aspek pasar atau komunal. Dari keempat aspek tersebut, tentu saja faktor SDM menjadi hal yang paling menentukan untuk pengembangan Bank Syariah. Karena SDM merupakan sumber daya yang mengoperasikan dan mengontrol keberadaan Bank Syariah secara langsung. Berdasarkan pemikiran tersebut, peneliti hanya akan membahas secara mendalam berkaitan dengan SDM.

Sementara, SDM yang dibutuhkan oleh Perbankan Syariah adalah SDM yang paham akan ilmu syariah dan ilmu perbankan murni. Seiring berkembangnya permintaan akan SDM seperti hal tersebut, membuat Perguruan Tinggi sebagai penyedia Pendidikan Tinggi mulai membuka Program Studi Perbankan Syariah, baik Perguruan Tinggi yang berada di bawah naungan Kemenristekdikti (Kementerian Riset, Teknologi, dan Pendidikan Tinggi) ataupun di bawah naungan Dikstis (Direktorat Pendidikan Tinggi Keagamaan Islam) Kemenag (Kementerian Agama). Dengan demikian, penelitian ini hanya akan berfokus untuk membahas bagaimana Perguruan Tinggi merespon tingginya permintaan akan SDM yang paham akan ilmu perbankan murni dan ilmu syariah.

\section{KAJIAN LITERATUR Pengertian Bank Syariah}

Menurut Undang-Undang No. 21 Tahun 2008 tentang Perbankan Syariah, Perbankan Syariah adalah segala sesuatu yang menyangkut tentang Bank Syariah dan Unit Usaha Syariah, mencakup kelembagaan, kegiatan usaha, serta cara dan proses dalam melaksanakan kegiatan usahanya. Muchtar, $d k k$ (2016: 119), menyebut secara umum Perbankan Syariah sebagai suatu sistem perbankan yang pelaksanaannya berdasarkan hukum Islam (syariah). Sedangkan Bank Syariah menurut Undang-Undang No. 21 Tahun 2008 Tentang Perbankan Syariah, adalah bank yang menjalankan kegiatan usahanya berdasarkan Prinsip Syariah, dan menurut jenisnya terdiri atas Bank Umum Syariah dan Bank Pembiayaan Rakyat Syariah. Sementara Prinsip Syariah adalah prinsip hukum Islam dalam kegiatan perbankan berdasarkan fatwa yang dikeluarkan oleh lembaga yang memiliki kewenangan dalam penetapan fatwa di bidang syariah.

Sedangkan fatwa ialah menerangkan hukum-hukum Allah SWT berdasarkan pada dalil-dalil syariah secara umum dan menyeluruh. Keterangan hukum yang telah diberikan itu dinamakan fatwa. Orang yang meminta atau menanyakan fatwa disebut mustafi, sedang yang diminta untuk memberikan fatwa disebut mufti (DSN-MUI, 2014: 8). Adapun lembaga yang memiliki kewenangan mengeluarkan fatwa di bidang syariah ialah DSN-MUI (DSN-MUI 2014: 4).

Sementara, Antonio (2016: 234) menyatakan bahwa DSN merupakan tempat berkumpulnya ulama yang berkompeten terhadap hukum-hukum syariah, yang memiliki fungsi dan peran amat besar dalam Perbankan Syariah. Dengan demikian, dapat diketahui bahwa Bank Syariah merupakan sistem perbankan yang dalam operasionalnya menggunakan hukum Islam, yang 
dikeluarkan sebagai fatwa oleh Dewan Syariah Nasional. Sedangkan sistem perhitungannya tidak menggunakan bunga, akan tetapi menggunakan sistem bagi hasil (profit sharing).

\section{SDM Bank Syariah}

Semula, SDM (Sumber Daya Manusia) merupakan terjemahan dari "human resources", namun ada pula ahli yang menyamakan SDM dengan "manpower" (tenaga kerja). Bahkan sebagian orang menyetarakan pengertian SDM dengan personal (personalia, kepegawaian, dan sebagainya) (Sutrisno, 2016: 3). Menurut Mangkupraja (2009: 178), SDM merupakan sosok manusia dalam organisasi, misalnya perusahaan, yang memiliki ciri-ciri sangat berbeda dengan sumber produksi lainnya seperti dengan capital atau teknologi, fasilitas, uang, tanah dan bahkan dengan ternak sebagai unsur produksi. SDM adalah manusia yang memiliki intuisi, emosi, akal, ambisi, harga diri, dan kepribadian aktif, sedangkan unsur produksi lainnya tidak demikian.

Dengan demikian, SDM adalah faktor sentral dalam suatu organisasi. Apapun bentuk serta tujuannya, organisasi dibuat berdasarkan berbagai visi untuk kepentingan manusia dan dalam pelaksanaannya, misi tersebut dikelola oleh manusia. Jadi manusia merupakan faktor strategis dalam semua kegiatan organisasi (Purnaya, 2016: 3). Maka dari itu, SDM yang digunakannya pun harus tangguh (Mangkupraja, 2009: 136).

Bagian yang mengelola SDM adalah Manajemen Sumber Daya Manusia (MSDM), atau departemen SDM. MSDM merupakan suatu perencanaan, pengorganisasian, pengarahan, dan pengawasan atas pengadaan, pengembangan, kompensasi, pengintegrasian, pemeliharaan, dan pemutusan hubungan kerja dengan maksud untuk mencapai tujuan organisasi perusahaan secara terpadu (Sutrisno, 2016: 7).

MSDM biasanya akan bertanggung jawab dalam pengembangan SDM yang dimiliki oleh perusahaan. Bisa dikatakan, maju atau mundurnya perusahaan, akan ditentukan oleh MSDM. Karena MSDM yang akan bertanggung jawab mengenai penempatan seluruh SDM yang ada di perusahaan. Menurut Sudjatmiko (2009: 39), secara umum sukses tidaknya departemen SDM adalah bagaimana mereka menunjang tercapainya tujuan perusahaan. Tujuan perusahaan biasanya ialah meningkatkan pangsa pasar atau keuntungan. Bila tujuan ini diterjemahkan ke departemen SDM, maka tujuan akhir departemen SDM ialah meningkatkan kinerja perusahaan secara keseluruhan.

Berbicara tentang SDM, Perbankan Syariah sebagai institusi bisnis tentunya membutuhkan SDM yang berkualitas dan mumpuni di masing-masing bidang kerja yang dibutuhkan. Apalagi, bila melihat keberadaan Perbankan Syariah yang berkembang pesat, tentu sangat membutuhkan SDM yang banyak. Hal tersebut untuk menopang kinerja bisnis perusahaan, demi memberikan pelayanan terbaik untuk konsumennya. 
Menurut Ifham (2008: 295) strategi pengembangan SDM yang dilakukan Bank Syariah harus mampu memastikan SDM yang ada memiliki kompetensi dan komitmen yang sesuai dengan fitur produk dan jasa yang ditawarkan, besarnya skala bisnis serta jaringan dan sistem teknologi informasi yang digunakan.

Kompetensi dan komitmen yang kuat dari diri SDM, akan menjadi kata kunci pengembangan Perbankan Syariah di Indonesia. Maka dari itu, harus ada kerjasama yang intensif antara Perbankan Syariah di Indonesia dengan Perguruan Tinggi. Sehingga Perguruan Tinggi mengetahui, SDM seperti apa yang dibutuhkan oleh industri Perbankan Syariah di Indonesia. Kemudian, hal tersebut akan disesuaikan dengan kurikulum yang disediakan oleh Perguruan Tinggi, untuk menghasilkan SDM seperti yang diharapkan.

Dari seluruh pemaparan berkaitan dengan SDM Perbankan Syariah, bila disimpulkan, masih kurangnya tenaga-tenaga yang yang menguasai dengan baik ilmu perbankan murni dan ilmu syariah sekaligus. Karena SDM yang kuat akan ikut mendorong pertumbuhan Bank Syariah ke depan. Oleh karena itu, pelatihan, penelitian, dan pengembangan ilmu-ilmu syariah dan perbankan perlu mendapatkan prioritas (Soemitra, 2015: 106).

Tentu saja, tantangan tersebut harus segera dicarikan solusi terbaik, agar penyediaan SDM untuk Perbankan Syariah dapat terselesaikan. Sehingga adanya solusi yang tepat untuk penyediaan SDM Perbankan Syariah, mampu berpengaruh terhadap peningkatan kualitas layanan Perbankan Syariah kepada para nasabahnya. Salah satu solusinya ialah, industri Perbankan Syariah harus aktif bersinergi dengan Perguruan Tinggi, khususnya Perguruan Tinggi yang menyediakan Program Studi Perbankan Syariah.

\section{Pendidikan Tinggi di Perguruan Tinggi}

Menurut Undang-undang No. 12 Tahun 2012 Tentang Pendidikan Tinggi, Pendidikan Tinggi adalah jenjang pendidikan setelah pendidikan menengah yang mencakup program diploma, program sarjana, program magister, program doktor, dan program profesi, serta program spesialis, yang diselenggarakan oleh Perguruan Tinggi berdasarkan kebudayaan bangsa Indonesia.

Sedangkan Perguruan Tinggi menurut Undang-undang No. 12 Tahun 2012 Tentang Pendidikan Tinggi, adalah satuan pendidikan yang menyelenggarakan Pendidikan Tinggi. Menurut Undang-Undang No. 20 Tahun 2003 Tentang Sistem Pendidikan Nasional, Perguruan Tinggi dapat berbentuk akademi, politeknik, sekolah tinggi, institut, atau universitas. Bentuk tersebut menyesuaikan kapasitas dari Perguruan Tinggi itu sendiri, yaitu kapasitas dari fakultas, program studi, dan juga para dosen yang dimiliki oleh Perguruan Tinggi itu sendiri. Kapasitas tersebut, akan membuat Perguruan Tinggi dapat menyelenggarakan pendidikan dengan baik dan sesuai yang diharapkan oleh konstitusi.

Sementara, menurut Irianto (2012: 7), Perguruan Tinggi yang berkualitas tidak hanya menghasilkan sarjana yang cerdas dan berdaya saing tetapi 
harus juga berkontribusi pada peningkatan kesejahtraan bangsa melalui pengetahuan dan budaya yang dikembangkannya. Di pihak lain, pemerintah dan dunia industri tentunya perlu disadarkan untuk mendukung dalam hal kebijakan dan pendanaan.

Sedangkan Menurut Djojodibroto (2004: 20), Perguruan Tinggi memproduksi sarjana dan menghasilkan intelektual. Menurutnya, seseorang disebut intelektual apabila memenuhi persyaratan, antara lain:

1. Berpendidikan Tinggi atau mempunyai pengetahuan setingkat dengan pengetahuan yang diberikan kepada lulusan pendidikan tinggi.

2. Berminat atau peduli pada masalah-masalah yang menyangkut nasib manusia yang berkaitan dengan moral dan politik.

3. Mampu menyatakan hasil pemikirannya, moral dan politik secara lisan maupun secara tertulis.

Seorang yang digolongkan sebagai intelektual selalu hidup di dunia ide. Mereka menyusun konsep dan skema moral untuk tujuan idenya. Oleh karena dunia ide tidak selalu sama dengan dunia nyata, maka seorang intelektual selalu melakukan kritik terhadap dunia nyata. Kritiknya selalu menghendaki perubahan agar dunia nyata mendekati harapan idenya. Demikianlah intelektual selalu bersifat kritis (Djojodibroto 2004: 20-21).

Dengan demikian, keberadaan Pendidikan Tinggi di Perguruan Tinggi salah satunya ialah untuk menghasilkan intelektual yang mampu menghasilkan ide-ide kreatif dalam kehidupan sehari-hari. Sehingga dengan banyaknya masyarakat yang mengikuti Pendidikan Tinggi di Perguruan Tinggi, akan banyak lahir manusia kreatif yang rahmatan lil alamien.

\section{METODE PENELITIAN}

Metode penelitian yang digunakan dalam penelitian ini adalah metode deskriptif dengan pendekatan kualitatif, yaitu penelitian yang menggambarkan data dan informasi di lapangan berdasarkan fakta yang diperoleh di lapangan secara mendalam (Arikunto, 1993: 309). Sementara, model penelitian kualitatif yang digunakan adalah studi kasus. Model ini memfokuskan pada kasus tertentu. Dimana, studi kasus adalah suatu model penelitian kualitatif yang terperinci tentang individu atau suatu unit sosial tertentu selama kurun waktu tertentu (Herdiansyah, 2010: 76).

Adapun jenis data yang digunakan dalam penelitian ini adalah data kualitatif dan kuantitatif. Data tersebut diperoleh peneliti dari Ketua Program Studi Manajemen Perbankan Syariah FAI-UMJ melalui staf yang ditugaskan di Program Studi yang bersangkutan. Kemudian, peneliti meminta data tambahan dari bagian akademik fakultas sebagai data pelengkap, dan juga meminta data ke bagian pengelola data di Fakultas Agama Islam UMJ.

Sedangkan sumber data ada dua, yaitu data primer dan data skunder. Data primer merupakan data yang dikumpulkan sendiri oleh periset. Sedangkan data sekunder merupakan data yang dikumpulkan oleh pihak lain (Istijanto, 2005: 26). Adapun data yang digunakan dalam penelitian ini menggunakan data primer dan data skunder. Data primer adalah hasil wawancara dan data 
lainnya yang diperoleh langsung dari sumbernya yaitu Program Studi Manajemen Perbankan Syariah FAI UMJ. Sedangkan data sekunder diperolah dari buku, artikel, jurnal, internet, dan berbagai sumber lainnya. Data primer dan data sekunder kemudian diolah dan dianalisis untuk mendapatkan kesimpulan.

Adapun fokus pertanyaan dalam penelitian ini, antara lain:

1. Bagaimana proses pengembangan pembelajaran Program Studi Manajemen Perbankan Syariah FAI UMJ dalam menyediakan SDM untuk Perbankan Syariah?

2. Bagaimana pengembangan kurikulum Program Studi Manajemen Perbankan Syariah FAI UMJ untuk menghasilkan SDM yang mampu menguasai ilmu perbankan murni dan ilmu syariah?

3. Bagaimana Strategi Program Studi Manajemen Perbankan Syariah FAI UMJ untuk menghasilkan lulusan unggul yang diminati oleh industri perbankan syariah?

\section{PEMBAHASAN}

\section{Sejarah Singkat Program Studi Manajemen Perbankan Syariah}

Program Studi Manajemen Perbankan Syariah didirikan tanggal 22 Oktober 2009, dengan SK Penyelenggaraan Dj.I/614/2009 tertanggal 22 Oktober 2009. Kampus beralamat di Jln. KH. Ahmad Dahlan, Cirendeu, Ciputat, Tangerang Selatan (forlap.ristekdikti.go.id). Prodi Manajemen Perbankan Syariah berada di bawah naungan Fakultas Agama Islam UMJ. Sementara, letak bangunan kampus berada di paling depan, setelah melalui pintu masuk Kampus UMJ.

Akreditasi pertama kali dilakukan di tahun 2013, dan mendapatkan nilai akreditasi B. Kemudian, di tahun 2017 kembali melakukan akreditasi yang kedua, dan mendapatkan nilai B. Sehingga, akreditasi yang dimiliki hingga saat ini masih terakreditasi degan nilai B. Sementara, gelar awal yang diberikan kepada lulusan ialah Sarjana Ekonomi Syariah (SE,Sy). Setelah ada pemberlakuan nominklatur baru, gelar yang diberikan ialah Sarjana Ekonomi (SE).

\section{Pengembangan Pembelajaran}

Metode pembelajaran yang digunakan terdiri dari dua, yaitu pembelajaran formal dan non-formal. Pembelajaran formal adalah pembelajaran yang dilaksanakan berdasarkan mata kuliah yang harus diambil selama mahasiswa mengikuti studi dalam kurun waktu yang telah ditentukan. Pembelajaran formal wajib diikuti oleh setiap mahasiswa hingga dirinya dinyatakan lulus oleh dosen dari masing-masing pengampu mata kuliah. Karena pembelajaran formal ini, akan berpengaruh terhadap kelulusan mahasiswa dalam menempuh studi strata satu di program studi bersangkutan secara langsung.

Dalam menjalankan pembelajaran formal, Prodi Manajemen Perbankan Syariah FAI UM melalui dosen yang ditugaskan, akan menyelenggarakan 
pembelajaran didasarkan kepada tiga metode, antara lain: metode ceramah, yaitu metode yang digunakan oleh dosen sebagai sarana untuk menyampaikan mata kuliah yang bersifat teoritik; metode penugasan, yaitu metode yang digunakan untuk menyampaikan mata kuliah yang berisi percampuran antara teori dan praktik; metode magang, yaitu metode yang dilaksanakan bekerjasama dengan industri Perbankan Syariah, yang ditempatkan di kantor pusat, kantor wilayah, kantor cabang, ataupun kantor cabang pembantu.

Sedangkan pembelajaran non-formal merupakan pembelajaran yang disediakan oleh kampus di luar pembelajaran formal. Hanya saja, dalam pembelajaran non-formal, setiap mahasiswa diberi kebebasan untuk mengikuti ataupun tidak mengikuti kegiatan pembelajaran tersebut. Karena, pembelajaran non-formal tidak memberikan dampak secara langsung terhadap penilaian mahasiswa selama menjalani studi di program studi bersangkutan. Akan tetapi, pembelajaran non-formal akan menjadi penambah bekal bagi mahasiswa setelah menyelesaikan pembelajaran di program studi bersangkutan.

Dalam menjalankan pembelajaran non-formal, Program Studi Manajemen Perbankan Syariah menyediakan tiga bentuk kegiatan, antara lain: kegiatan Himpunan Mahasiswa Manajemen Perbankan Syariah (Hima MPS), yaitu bentuk kegiatan yang disediakan oleh fakultas untuk mengakomudir para mahasiswa yang akan mengembangkan diri dengan lebih menitikberatkan terhadap keilmuan berkaitan dengan prodi; kegiatan Badan Eksekutif Mahasiswa-Fakultas Agama Islam (BEM FAI), yaitu lembaga kemahasiswaan yang berada di bawah fakultas, yang kegiatannya bersifat umum; Kegiatan Ikatan Mahasiswa Muhammadiyah-Fakultas Agama Islam (IMM-FAI), yaitu kegiatan kemahasiswaan yang memadukan antara kegiatan pergerakan dan intelektual.

\section{Profil Lulusan}

Ada 3 jenis profil lulusan yang dikembangkan oleh Program Studi Manajemen Perbankan Syariah, Fakultas Agama Islam, UMJ, antara lain:

\section{Praktisi Perbankan dan Keuangan Syariah}

Profil lulusan sebagai praktisi perbankan dan keuangan syariah merupakan lulusan yang dipersiapkan untuk menjadi pelaku atau SDM yang siap berkecimpung di lembaga keuangan syariah, khususnya perbankan syariah. Program Studi Manajemen Perbankan Syariah akan membekali setiap lulusan dengan kemampuan operasional dan manajerial, penguasaan teknologi serta berkarakter jujur, amanah, inovatif dan profesional.

\section{Konsultan Perbankan dan Keuangan Syariah}

Profil lulusan sebagai konsultan perbankan dan keuangan syariah merupakan lulusan yang dipersiapkan untuk terjun sebagai konsultan keuangan syariah. Program Studi Manajemen Perbankan Syariah FAI UMJ akan membekali kemampuan untuk menyusun perencanaan, pendampingan dan problem solving permasalahan keuangan syariah yang ada di lembaga 
keuangan syariah pada umumnya, dan lembaga perbankan syariah pada khususnya.

\section{Enterpreneur Keuangan Syariah}

Profil lulusan sebagai entrepreneur keuangan syariah merupakan lulusan yang dipersiapkan untuk berprofesi sebagai pebisnis di bidang keuangan syariah. Program Studi Manajemen Perbankan Syariah akan membekali dengan kemampuan komunikasi yang berlandaskan etika bisnis Islam, sehingga mampu membangun relasi, menangkap peluang bisnis dan peka terhadap masalah bisnis keuangan syariah yang ada di Indonesia.

\section{Distribusi Mata Kuliah, Jumlah Mahasiswa dan Dosen}

Selama mengikuti kuliah, mata kuliah yang harus diambil oleh setiap mahasiswa per semester sebanyak 62 mata kuliah dengan jumlah SKS sebanyak 150 SKS, dan ditempuh selama 4 tahun atau 8 semester.

Sementara, untuk jumlah mahasiswa semenjak dibuka di tahun 2009 hingga tahun 2018 ini, keberadaan Prodi Manajemen Perbankan Syariah FAI UMJ cukup diminati. Hal tersebut, nampak dari jumlah kenaikan mahasiswa setiap tahunnya, setelah dikurangi antara mahasiswa yang masuk dengan mahasiswa yang lulus. Perhitungan tren kenaikan, dapat dilihat semenjak tahun 2013, karena di tahun 2013 tersebut, Prodi Manajemen Perbankan Syariah pertamakali meluluskan mahasiswa. Untuk mengetahui tren kenaikan, dapat dilihat dalam tabel di bawah ini:

\section{Tabel 2}

Jumlah Mahasiswa Prodi Manajemen Perbankan Syariah FAI UMJ Tahun 2009-2019

\begin{tabular}{c|c|c}
\hline No & Tahun & Jumlah Mahasiswa \\
\hline 1 & 2009 & 69 \\
\hline 2 & 2010 & 117 \\
\hline 3 & 2011 & 232 \\
\hline 4 & 2012 & 321 \\
\hline 5 & 2013 & 359 \\
\hline 6 & 2014 & 459 \\
\hline 7 & 2015 & 471 \\
\hline 8 & 2016 & 502 \\
\hline 9 & 2017 & 516 \\
\hline 10 & 2018 & 507
\end{tabular}

Sumber: Forlap Ristekdikti, 2019

Adapun untuk tenaga pengajar yang dimiliki oleh Program Studi Manajemen Perbankan Syariah FAI UMJ terdiri dari dua jenis pengajar, yaitu dosen tetap dan dosen non-tetap (dosen terbang). Ketua Prodi akan memberikan setiap tenaga pengajar mata kuliah sesuai keahlian, baik untuk tenaga pengajar tetap ataupun non-tetap.

Sementara, untuk setiap dosen tetap yang diangkat oleh BPH-UMJ (Badan Pengurus Harian-Universitas Muhammadiyah Jakarta) diberi kewajiban 
untuk mengajar minimal 12 SKS. Adapun mata kuliah yang diberi, akan disesuaikan dengan latar belakang keilmuan dan keahlian keilmuan yang sedang digeluti dan dikembangkan oleh dosen bersangkutan. Mengacu terhadap data yang disediakan di Pangkalan Data Pendidikan Tinggi Kementerian Riset, Teknologi dan Pendidikan Tinggi, jumlah dosen tetap yang dimiliki oleh Program Studi Manajemen Perbankan Syariah sebanyak 6 orang.

Sedangkan untuk dosen non-tetap, akan diberikan mata kuliah sesuai dengan latar belakang pendidikan dan keahlian yang dimiliki oleh dosen tersebut. Dosen non-tetap bisa berasal dari dosen di luar Program Studi Manajemen Perbankan Syariah, luar Fakultas Agama Islam, dan luar Universitas Muhammadiyah Jakarta. Salah satu tujuan menggunakan dosen non-tetap ialah, untuk memberikan dinamika keilmuan yang lebih dinamis sesuai dengan latar belakang keilmuan para pengajar. Adapun jumlah dosen tetap untuk Program Studi Manajemen Perbankan Syariah sebanyak 33 dosen.

\section{Rasio Dosen Terhadap Jumlah Mahasiswa}

Rasio dosen dengan jumlah mahasiswa menjadi hal yang sangat penting untuk diketahui. Dimana, rasio dosen didapatkan melalui perbandingan antara jumlah dosen tetap dengan jumlah mahasiswa. Idealnya, rasio dosen dengan jumlah mahasiswa ialah 1:30 (1 dosen banding 30 mahasiswa) atau bahkan maksimal 1:40 (1 dosen banding 40 mahasiswa).

Berdasarkan hasil analisis antara jumlah dosen tetap dengan jumlah mahasiswa yang dimiliki oleh Program Studi Manajemen Perbankan Syariah FAI UMJ, rasio dosen dengan mahasiswa untuk tahun akademik 2018-2019 sebesar 1 : 84 (1 dosen sebanding 84 mahasiswa). Tentu saja, jumlah tersebut sangat jauh dari rasio maksimal berkaitan dengan rasio dosen. Dimana, bila rasio maksimal dosen 1: 40 mahasiswa, berarti Program Studi Manajemen Perbankan Syariah harus menyediakan dosen sejumlah 12 dosen tetap. Artinya, Prodi harus menambah jumlah dosen sebanyak 6 dosen tetap ke depannya.

Berdasarkan hasil analisis data dari dosen (dosen tetap atapun non-tetap) yang dimiliki oleh Prodi Manajemen Perbankan Syariah FAI-UMJ, untuk tingkat pendidikan dosen tetap yang bergelar doktor (S3) baru ada 1 orang, sisanya 5 dosen masih bergelar magister (S2). Sementara untuk Jabatan fungsional, dari 6 dosen yang ada, 4 memiliki jabatan fungsional Asisten Ahli (AA), dan untuk 2 orang baru Tenaga Pengajar (TP).

Sedangkan dosen non-tetap, untuk semester genap tahun ajaran 2018-2019 berjumlah 33 dosen. Dari jumlah 33 dosen tersebut, yang bergelar doktor (S3) sebanyak 11 dosen dan sisanya 22 dosen bergelar magister (S2). Adapun latar belakang dosen bermacam-macam, ada yang berlatar belakang pendidikan, syariah, hukum, ekonomi, dan lain sebagainya. Latar belakang dosen non-tetap disesuaikan dengan mata kuliah yang diampuh oleh masingmasing dosen yang bersangkutan. 
Dengan demikian, jumlah dosen tetap dan non-tetap yang mengajar sebanyak 39 dosen, untuk semester genap tahun ajaran 2018-2019. Bila dilihat persentase perbandingan antara dosen tetap dengan dosen non-tetap, untuk dosen tetap berjumlah $15 \%$ dan non-tetap 85\%. Sedangkan perbandingan dosen (tetap dan non-tetap) yang memiliki pendidikan S2 dan S3, untuk S2 sebesar 69\%, dan untuk S3 sebesar 31\%.

\section{Orientasi Kurikulum Terhadap Dunia Industri}

Peneliti akan coba menganalisis orientasi kurikulum dengan dunia industri menggunakan pendekatan analisis tema mata kuliah yang diberikan dengan profil lulusan yang akan diciptakan. Dimana, profil lulusan yang diselenggarakan oleh Prodi Manajemen Perbankan Syariah FAI UMJ ialah bankir syariah dan konsultan perbankan syariah. Pendekatan yang dilakukan ialah, seberapa besar tema mata kuliah yang menitikberatkan terhadap pemberian keahlian di bidang perbankan secara langsung kepada para mahasiswa, dari seluruh mata kuliah yang diberikan kepada mahasiswa selama mengenyam pendidikan sarjana di Prodi Manajemen Perbankan Syariah FAI UMJ.

Jumlah mata kuliah yang diberikan selama mengikuti pendidikan S1 di Prodi Manajemen Perbankan Syariah FAI UMJ sebanyak 62 mata kuliah dengan jumlah SKS sebanyak 150 SKS. Dari 62 mata kuliah, dikelompokkan menjadi 5 kelompok, yaitu: Kompetensi Dasar (KD), Kompetensi Utama (KU), Kompetensi Pendukung (KP), Kompetensi Keahlian (KK), dan Karya Ilmiah (KI). Bila dikelompokkan, akan tampak seperti tabel 3 di bawah ini:

Tabel 3

Distribusi Mata Kuliah Berdasarkan Kompetensi

\begin{tabular}{c|c|c|c}
\hline No & Keterangan & Mata Kuliah & SKS \\
\hline 1 & Kompetensi Dasar (KD) & 14 & 28 \\
\hline 2 & Kompetensi Utama (KU) & 25 & 61 \\
\hline 3 & $\begin{array}{c}\text { Kompetensi Pendukung } \\
(\mathrm{KP})\end{array}$ & 12 & 32 \\
\hline 4 & Kompetensi Keahlian (KK) & 8 & 21 \\
\hline 5 & Karya Ilmiah (KI) & 3 & 8 \\
\hline \multicolumn{2}{c}{ Jumlah } & $\begin{array}{c}\text { 62 Mata } \\
\text { Kuliah }\end{array}$ & $\mathbf{1 5 0}$ SKS
\end{tabular}

Pengelompokan kurikulum yang diberlakukan di Prodi Manajemen Perbankan Syariah FAI UMJ mengacu terhadap UU No. 12 Tahun 2012 Tentang Pendidikan Tinggi, Perpres No. 08 Tahun 2012 Tentang KKNI, dan Permenristekdikti No. 44 Tahun 2015 Tentang SN-Dikti. Regulasi tersebut, menjadi acuan dalam pengembangan kurikulum. Salah satu tujuannya, agar taat norma yang dikeluarkan oleh pemerintah, juga untuk meningkatkan kualitas pendidikan tinggi yang diselenggarakan oleh Prodi Manajemen Perbankan Syariah FAI UMJ. 


\section{SIMPULAN}

Berdasarkan temuan dan pembahasan pada bab sebelumnya, diperoleh kesimpulan sebagai berikut:

1. Pengembangan pembelajaran yang dilakukan oleh Prodi Manajemen Perbankan Syariah menggunakan metode pembelajaran formal dan nonformal, yang keduanya didesain untuk membentuk mahasiswa agar memiliki kemampuan sebagai seorang bankir yang memiliki keahlian di bidang ilmu perbankan murni dan ilmu syariah.

2. Pengembangan kurikulum dilakukan dengan cara mendesain mata kuliah yang disesuaikan dengan profil lulusan prodi, yaitu praktisi di Bank Syariah, konsultan perbakan dan keuangan syariah, serta enterpreneur keuangan syariah.

3. Strategi yang digunakan untuk menghasilkan lulusan unggul yang diminati oleh industri ialah, dengan mengenalkan konsep teori dan praktik berkaitan dengan ilmu perbankan murni dan ilmu syariah.

Bagi peneliti selanjutnya yang tertarik untuk melakukan penelitian berkaitan dengan pengembangan SDM Syariah melalui perguruan tinggi, peneliti sangat menyarankan untuk melakukan penelitian lebih mendalam dari penelitian yang telah dilakukan ini. Bahkan, peneliti sangat menyarankan untuk melakukan penelitian melalui studi komparasi dengan Program Studi yang sejenis di Perguruan Tinggi lainnya.

\section{DAFTAR PUSTAKA}

Abrar, Tanveer; Ahmed, Farhan; Kashif, Muhammad. (2018). Financial Stability of Islamic Versus Conventional Banks in Pakistan. Al-Iqtishad: Jurnal Ilmu Ekonomi Syariah (Journal of Islamic Economics), Volume 10 (2). 341-366.

Aisyah, Muniaty. (2018). Islamic Bank Service Quality and It's Impact on Indonesian Customers' Satisfaction and Loyalty, Al-Iqtishad: Jurnal Ilmu Ekonomi Syariah (Journal of Islamic Economics), Volume 10 (2). 367388.

Anggraini, Rachmasari; Rohmati, Dani; Widiastuti, Tika. (2018). Maqāṣid alSharīah Sebagai Landasan Dasar Ekonomi Islam. Economica: Jurnal Ekonomi Islam, Volume 9, Nomor 2. 295-317.

Antonio, Muhammad Syafii. (2016). Bank Syariah: Dari Teori ke Praktik. Jakarta: Gema Insani.

Arikunto, Suharsimi. (1993). Manajemen Penelitian, Jakarta: PT Rineka Cipta.

Dhiba, Nadhiera Ahya; Esya, Lavlimatria; Galerry, Citra. (2019). Pengaruh NPF, BOPO dan SBIS Terhadap Pertumbuhan Aset Perbankan Syariah di Indonesia, Jurnal Media Ekonomi, Vol. 27, No. 1. 9-16.

Djojodibroto, R. Darmanto. (2004). Tradisi Kehidupan Akademik, Yogyakarta: Galang Press. 
Hani Werdi Apriyanti. (2018). Model Inovasi Produk Perbankan Syariah di Indonesia, Economica: Jurnal Ekonomi Islam, Volume 9, Nomor 1, 83104.

Herdiansyah, Haris. (2010). Metodologi Penelitian Kualitatif untuk Ilmu-Ilmu Sosial, Jakarta: Penerbit Salemba Humanika.

https://forlap.ristekdikti.go.id/prodi/detail/NEQ0MjdENTgtNTdEMi00MTE 5LTk4MTctODkwOERFQUM0NTM0/0.

Irianto, Sulistyowati. (2012). Otonomi Perguruan Tinggi Suatu Keniscayaan, Jakarta: Yayasan Pustaka Obor Indonesia.

Kayadibi, Saim. (2019). The State As An Essential Value (Ḍarūriyyāt) of the Maqāṣid Al-Sharī'ah, Jurnal Ahkam, Volume 19, Number 1.1-18.

Kementerian Agama Republik Indonesia. (2016). Masterplan Arsitektur Keuangan Syariah di Indonesia, Jakarta: Kementerian Agama Republik Indonesia, Direktorat Jendral Bimbingan Masyarakat Islam dan Direktorat Pemberdayaan Zakat dan Wakaf.

Majelis Ulama Indonesia. (2014) Himpunan Fatwa Keuangan Syariah: Dewan Syariah Nasional MUI, Jakarta: Penerbit Erlangga.

Mangkupraja, Tb. Sajfri. (2009) Bisnis, Manajemen, dan Sumberdaya Manusia, Cet. Kedua, Bogor: IPB Press.

Muchtar, Bustari, dkk. (2016). Bank dan Lembaga Keuangan Lain, Jakarta: Prenadamedia Group.

Otoritas Jasa Keuangan (OJK), Sistem Perbankan Syariah (SPS) Baru, Jakarta: OJK, 2018, Diakses Dari: https://ojk.go.id/id/kanal/syariah/data-danstatistik/statistik-perbankan-syariah/Default.aspx, tanggal 8 Mei 2019.

PBI No. 13/25/PBI/2011 tentang Penerapan Manajemen Risiko bagi Bank Umum Syariah dan Unit Usaha Syariah.

PBI No 17/11/2015 Tentang Perubahan Atas Peraturan Bank Indonesia Nomor 15/15/PBI/2013 Tentang Giro Wajib Minimum Bank Umum Dalam Rupiah dan Valuta Asing Bagi Bank Umum Konvensional.

POJK, No. 15/POJK.03/2017 Tentang Penetapan Status dan Tindak Lanjut Pengawasan Bank Umum.

Perpres No. 08 Tahun 2012 Tentang KKNI. Kerangka Kualifikasi Nasional Indonesia

Permenristekdikti No. 44 Tahun 2015 Tentang Standar Nasional Pendidikan Tinggi

Rodoni, Ahmad; Yaman, Bahrul. (2018) Asymmetric Information and NonPerforming Financing: Study in The Indonesian Islamic Banking Industry, Al-Iqtishad: Jurnal Ilmu Ekonomi Syariah Uournal of Islamic Economics), Volume 10 (2). 403-416.

Rusydiana, Aam Slamet. (2016) Analisis Masalah Pengembangan Perbankan Syariah di Indonesia: Aplikasi Metode Analitycal Network Proces, Esensi: Jurnal Bisnis dan Manajemen, Vol. 6, No. 2. 237-246.

Saekhu. (2017). Dampak Indikator Makro Ekonomi Terhadap Dana Pihak Ketiga Perbankan Syariah, Economica: Jurnal Ekonomi Islam, Volume 8, Nomor 1. 103-130. 
Soemitra, Andri. (2015). Bank dan Lembaga Keuangan Syariah, Jakarta: Prenadamedia Group.

Solihin, Ahmad Ifham. (2008). Ini Lho, Bank Syariah!, Jakarta: PT Grafindo Media Media Pratama.

Sudjatmiko, Stive. (2009). Mengapa Departemen SDM Dibenci?, Jakarta: PT Gramedia Pustaka Utama.

Sutrisno, Edy. (2016). Manajemen Sumber Daya Manusia, Cet. 8, Jakarta: Kencana Prenada Media Group.

Tim Katadata, Indonesia, Negera Berpenduduk Muslim Terbesar, Jakarta: katadata.co.id, 2016. Diakses Dari: https://databoks.katadata.co.id/datapublish/2016/11/11/indonesianegara-berpenduduk-muslim-terbesar-dunia, tanggal 8 Mei 2019.

Undang-Undang No. 12 Tahun 2012 Tentang Pendidikan Tinggi.

Undang-Undang No. 20 Tahun 2003 Tentang Sistem Pendidikan Nasional. 
Hamli Syaifullah

Halaman ini sengaja dikosongkan 